simple dissuasion, clinging instead to the notion of absolute protection through nuclear weapons. Charpak and Garwin propose a form of disarmament in which most nuclear warheads are rapidly scrapped and the components put into storage, while a minimal number of weapons are primed for launching. But how small is minimal?

In considering the advisability, even the necessity, of nuclear testing, slight differences emerge in the American and European viewpoints. The authors concur on specific proposals for a massive and rapid reduction in stockpiles of nuclear weapons. The United States and Russia should cut their respective arsenals to 2,000 warheads over the next two years, and the three other self-confessed nuclear powers would start scaling down their own nuclear weaponry once the American and Russian stocks descend below 1,000. A worldwide treaty could then be negotiated for the complete elimination of nuclear weapons.

The authors take as the title to their conclusion "Scientists, politicians, utopians, realists, ecologists: a common purpose". They may have cast their net wide, but who would criticize them?

Charpak and Garwin have written an excellent book in which they clearly separate comment and interpretation from information. This allows readers to learn without losing the freedom to make judgements for themselves, guided in their decisions by two trusty advocates.

Hubert Curien is the president of the Academia

Europaea, and is emeritus professor of crystallography at the University of Paris, Paris 75252, France.

\section{Gladiator for science}

\section{Huxley: Evolution's High Priest}

by Adrian Desmond

Michael Joseph: 1997. Pp. 340. £20

\section{Crispin Tickell}

This is the second part of Adrian Desmond's biography of Thomas Henry Huxley, and covers the period between 1870 and his death in 1895. It follows, rather awkwardly, from the first part (published in 1994 and reviewed in Nature 375, 300-301; 1994) as if the reader had just put the latter down and was still familiar with the cast of characters. This second part draws upon material from London's Imperial College that was not available to previous biographers.

During his life, and afterwards, Huxley was given many labels: 'Darwin's bulldog', 'Pope Huxley', 'Huxley Eikonoklastes', 'the devil's disciple' and now 'evolution's high priest'. In my view, these are misleading in different ways. During the great changes in nineteenth-century thinking about the natural world, Huxley was more of a partner to

\section{IMAGE UNAVAILABLE FOR COPYRIGHT REASONS}

'Darwin's bulldog': T. H. Huxley, painted by Alphonse Legros.

Darwin than his bulldog or disciple. He reproached himself for not having spotted the processes of natural selection, but his particular and crowning achievements lay elsewhere. More than anyone, he established the central role of science in a society living in an intellectual world remote from our own. Together, he and Darwin shifted the paradigm, in what was then the leading country of the world, in a fashion that can be compared with Newton's achievements almost 200 years before. Huxley did for science what others have since tried to do for the environment. The statues of Huxley and Darwin stand benevolently together in London's Natural History Museum.

Huxley was a man of amazing parts. Born in a relatively poor dissenting family, he learned how to infiltrate the ruling establishment by speaking its language and understanding its ways. Establishments rarely mind radicals if they can present themselves wearing best bib and tucker. Huxley became a member of the Athenaeum, president of the Royal Society and, eventually, a privy counsellor. In some respects, he was a conservative (with a small ' $c$ '), and suspicious of socialism and the political revolutionaries of his time.

This respectability helped him to carry out an expert demolition job on some religious beliefs, and particularly on the Church itself. Just before his death he wrote: "I am not afraid of the priests in the long run. Scientific method is the white ant which will slowly but surely destroy their fortifications." But he became something of a priest himself, not so much of evolution (as suggested in the subtitle of this book), but of agnosticism (his own word) and of an approach encapsulated in a letter he wrote in 1886: "I am too much of a sceptic to deny the possibility of anything." Thus he long held back, at least in public, from unqualified endorsement of evolution by natural selection, and described theories as "excellent servants but verybad masters".

Not least, Huxley was a creative scientist, combining detailed practical work in the laboratory with the rare gift of exposition of general ideas. Looking back, it is fascinating how far he saw ahead, predicting, for example, the role of living organisms in shaping their physical environment (now part of Gaia theory); the way that Penicillium mould stops bacterial growth; the likelihood that birds descended from dinosaurs; and the doctrine of garbage in, garbage out. As a prolific intellectual bruiser, he was without peer in his time. Woe betide those who wandered into his sights: from Bishop Wilberforce in 1860 to the ageing Gladstone in the 1880s, Huxley dealt with them in crisp and, above all, decisive fashion. He also enjoyed wide popularity. For the young H.G. Wells, he was a continuing inspiration. On Huxley's death, a dock labourer, living, as he wrote, from hand to mouth, sent a shilling postal order as a contribution to his memorial.

The role Huxley played was achieved at some personal cost. He was subject to depression and always felt driven. Until near the end, he was usually short of money. Although he was the patriarch of a happy extended family with a much-loved wife, his eldest son died in infancy, his siblings suffered a variety of misfortunes and the most talented of his daughters suffered from mental instability and died young. Any charges of immorality aimed at his thinking did not extend to his way of life. Even so, his eldest granddaughter remembered being ostracized at school for her descent from 'the great atheist', and he was the object of abuse from zealots who wrote during his last illness to rejoice in his coming prospects in hell.

Adrian Desmond brings together new information about Huxley and presents it in lively, albeit breathless, fashion. I found the best and most illuminating part occurred towards the end of the book, when Desmond seeks to place his subject in historical perspective. For the life itself, he chooses to write according to a "ciné theory of narration... a highly mediated celluloid construct, where the camera pans across a stage". I do not think this method works very well, and I hope it does not become a model for others. Too often, the result is a cross between Time magazine and television soundbites, in which continuity and coherence are lost. Clichés pile up: "the old world scornfully eyed the new"; people "chortle", "crow", "chuckle"; and so on. The book as a whole is a stock cube in need of hot water to make it digestible.

Yet it brings out facts about Huxley that are new, and there are insights of real value. It is the product of painstaking research and will itself become part of the archive. Huxley 
once admitted that mildness in one of his articles was not "the softness of the answer which turneth away wrath, but... that of the pillow which smothered Desdemona". As the foremost gladiator of science in his day, he knew how to use every weapon. He thereby changed the mind of his own generation and of our own as well.

Sir Crispin Tickell is at Green College, University of Oxford, Woodstock Road, Oxford OX2 6HG, UK.

\section{Roots theories and} racist interpretations

\section{Race and Human Evolution: A Fatal} Attraction

by Milford Wolpoff and Rachel Caspari

Simon \& Schuster: 1996. Pp. 462. \$25, E17.99.

Leslie C. Aiello

This book attempts to answer one of the most fundamental questions of human existence: why are we here? In doing this, the authors put forward one of the best and most clearly articulated cases so far for the multiregional theory of modern human origins. Perhaps more importantly, they couch their description and defence of this theory in the context of the intermeshed history of human origins studies, racism and politics. For this reason alone, students of human evolution should read and take heed of this book. It is too easy for us to sit in our universities and ignore the intellectual history of the theories that we put forward and the ways in which they may be manipulated by the political and cultural contexts in which we work.

Wolpoff and Caspari are careful to define multiregionalism as a theory that suggests that for some two million years human populations have been entwined in a network of widespread peoples who evolved together because they met and interbred, giving the races today many ancestors, not a single common one. This gloss on multiregionalism is different from that commonly associated with the theory by the popular press and many who argue against the idea.

The popular interpretation of multiregionalism is that races of Homo erectus in Africa, Asia and Europe gave rise to the modern human races living in those areas of the world. The implication is that, during the long course of evolution, isolation rather than continuity was the rule. Wolpoff and Caspari argue strongly that this unjustified emphasis on isolation in human evolution exposes the theory of multiregionalism to equally unjustified racist interpretations. At the same time, they stress that it also renders the theory unreasonable in the context of Darwinian evolution. Throughout the book, they return again and again to the point that modern multiregionalism is not a polygenetic theory of racial evolution.

\section{IMAGE UNAVAILABLE FOR COPYRIGHT REASONS}

A Homo erectus skull: racism rears its ugly head in interpretations of human origins.

Polygenism is the largely nineteenth-century idea that human races have different origins and separate histories. Most polygenetic theories formulated after Darwin posited some type of orthogenetic impetus driving the evolution of these isolated races in the same general direction. The more separate the human races are, the easier it is to argue that some humans are more human than others, and to build a justification for colonialism, racism and slavery. This is precisely how these theories were used.

Wolpoff and Caspari show that, although polygenism is a convenient prerequisite to racism, all polygenists were not necessarily racists, and that all adherents of the alternative view, monogenism, were not necessarily enlightened egalitarians. Rather, racism then as well as now is governed by a complicated interplay of influences from natural history and taxonomic thinking, religion, politics and, from the middle of the nineteenth century, Darwinism in its various guises. Much of the core of the book traces these various threads through the personalities involved in late nineteenth and early twentieth century physical anthropology and racial studies. In so doing, it establishes intellectual genealogies which make fascinating reading for anyone familiar with the work of the personalities involved.

This discussion sets the stage for the defence of one of the most respected hominid anatomists of the twentieth century, Franz Weidenreich, and his perhaps less respected polycentric theory of human origins. It is no accident that the book builds up to this climax, because Weidenreich's polycentric theory is the immediate intellectual forerunner of multiregionalism. Wolpoff and Caspari argue strongly that Weidenreich viewed human races as continuous, interconnected and ephemeral entities with considerable time depth. To their mind, poly- centrism has been seriously misrepresented by modern palaeoanthropology as simply another polygenetic theory, incompatible with modern evolutionary biology and open to racist interpretations.

By association, they also feel that multiregionalism is unjustifiably tainted. Wolpoff and Caspari are also careful to distance multiregionalism from another and perhaps infamous version of polycentrism put forward in the 1960 s by Carlton Coon. In emphasizing the discontinuous nature of human races, Coon's theory harks back to some of the worst excesses of nineteenthcentury academic racism.

On this basis, the last three chapters of the book are devoted to the defence of modern multiregionalism. Most of the arguments presented are well known to palaeoanthropologists, but the clarity with which they are presented makes Race and Human Evolution a welcome contribution to the literature. However, the book is not in itself going to convince the majority of the academic community that alternative single-origins theories for the evolution of modern humans are dead. This is particularly the case because Wolpoff and Caspari insist on polarizing the debate. They argue against what they insist on calling the "Eve theory", the most extreme version of a variety of single-origins models for modern human evolution.

The real question is whether their own theory of multiregionalism is genetically viable. Is it really possible that modern human features could have arisen individually and at different times and places throughout the vast geographical range occupied by Pleistocene human populations, and coalesced into modern humans and modern human diversity as we know it today? Many palaeoanthropologists and evolutionary biologists will remain to be convinced even after reading this book. We can expect this lively debate to continue for a long while to come.

Leslie C. Aiello is in the Department of Anthropology, University College London, Gower Street, London WC1E 6BT, UK.

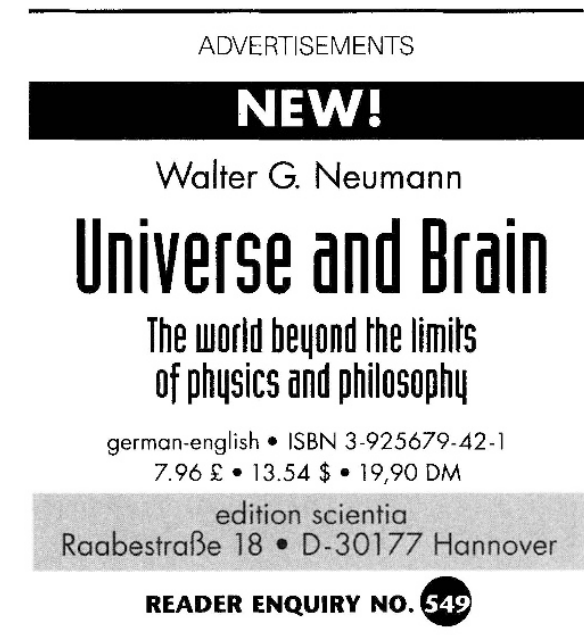

